\title{
Pengaruh Pemasaran Langsung Dan Promosi Penjualan Terhadap Keputusan Pembelian Produk Wardah Exclusive Matte Lip Cream Di Tokopedia
}

\author{
Widita Putri Oktavania \\ London School of Public Relations - Jakarta \\ widitaputrio@yahoo.com
}

\begin{abstract}
Abstrak. Penelitian ini meneliti tentang pengaruh pemasaran langsung dan promosi penjualan terhadap keputusan pembelian produk Wardah Exclusive Matte Lip Cream di Tokopedia. Penelitian ini bertujuan untuk menguji dan menganalisis mengenai pengaruh pemasaran langsung dan promosi penjualan terhadap keputusan pembelian produk Wardah Exclusive Matte Lip Cream khususnya di Tokopedia. Konsep yang digunakan dalam penelitian ini adalah bauran promosi, pemasaran langsung, promosi penjualan dan keputusan pembelian. Penelitian ini menggunakan metode kuantitatif dengan pendekatan survei. Pengumpulan data dilakukan dengan menyebarkan kuesioner secara online dengan jumlah responden sebanyak 107 orang. Pengambilan sampel dilakukan dengan teknik simple random sampling. Hasil penelitian menunjukkan bahwa pemasaran langsung tidak berpengaruh secara parsial terhadap keputusan pembelian dan promosi penjualan berpengaruh secara parsial terhadap keputusan pembelian dari produk Wardah Exclusive Matte Lip Cream di Tokopedia serta pemasaran langsung dan promosi penjualan berpengaruh secara simultan terhadap keputusan pembelian dari produk Wardah Exclusive Matte Lip Cream di Tokopedia.
\end{abstract}

\section{Kata kunci: pemasaran langsung, promosi penjualan, keputusan pembelian}

Abstract. This research examines about the impact of direct marketing and sales promotion on the purchase decision of Wardah Exclusive Matte Lip Cream in Tokopedia. This research aims to test and analyze the impact of direct marketing and sales promotion on the purchase decision Wardah Exclusive Matte Lip Cream especially in Tokopedia. Concept used in this research is promotion mix, direct marketing, sales promotion and purchase decision. This research used quantitative methods with survey approach. The data was collected by distributing online questionnaires with a total of 107 respondents. This sampling is taken through simple random sampling technique. The research results showed that direct marketing had no a partial impact on the purchasing intention and sales promotion had a partial impact on the purchasing decision of Wardah Exclusive Matte Lip Cream in Tokopedia and direct marketing and sales promotion had a simultan impact on the purchasing decision of Wardah Exclusive Matte Lip Cream in Tokopedia.

Keywords: direct marketing, sales promotion, purchase decision 


\section{Pendahuluan}

Pertumbuhan teknologi komunikasi dan internet yang semakin pesat di era modern ini menyebabkan perusahaan - perusahaan di Indonesia baik besar maupun kecil beralih ke arah digital, salah satunya adalah e-commerce. Ecommerce terdiri dari huruf ' $\mathrm{e}$ ' yang merupakan singkatan dari elektronik dan 'commerce' yang berarti perdagangan (Maryanto, 2017). Berdasarkan hasil survei yang dilakukan oleh Shopback Indonesia pada 2.400 responden di 7 kota, terlihat bahwa 92,3\% responden makin sering berbelanja online dibanding tahun lalu. Bahkan mereka kini mengaku makin jarang berbelanja offline karena semakin banyaknya jumlah e-commerce di Tanah Air (Rahman, 2017). Seperti data sensus ekonomi 2016 dari Badan Pusat Statistik (BPS) yang juga menyebutkan bahwa dalam 10 tahun terakhir, industri e-commerce di Indonesia mengalami pertumbuhan sekitar $17 \%$ dari total e-commerce mencapai 26,2 juta unit (Abdurrahman, 2017).

Salah satu pasar e-commerce di Indonesia adalah Tokopedia, yang merupakan platform untuk jual beli secara online yang sudah dikenal oleh masyarakat Indonesia. Startup tersebut didirikan oleh William Tanuwijaya dan Leontinus Alpha Edison karena mereka sadar kalau belum ada marketplace untuk memfasilitasi jual beli yang aman dan nyaman di Indonesia. Akhirnya ide tersebut terealisasikan dan website Tokopedia diluncurkan pada 17 Agustus 2009 (Noviandari, 2014). Dari hasil survei yang telah dilakukan oleh perusahaan konsultan TI Sharing Vision pada bulan Oktober hingga November 2017, didapat bahwa Tokopedia dipilih sebagai pilihan pertama untuk berbelanja online dengan jumlah sebanyak $66 \%$ suara responden (Kusumaningrum, 2018).

Tokopedia menjual berbagai macam produk yang dipisahkan menjadi beberapa kategori produk, misalnya seperti fashion, kecantikan, kesehatan, rumah tangga, elektronik, buku, makanan dan minuman hingga berbagai macam pembayaran dan top up. Tokopedia juga memudahkan para pembeli dengan adanya 'Hot List' yang merupakan kumpulan dari produk yang sedang tren atau populer dari berbagai toko atau online shop di Tokopedia dan Lip Cream Wardah (Exclusive Matte Lip Cream) menjadi salah satu kosmetik yang populer di Tokopedia (Tokopedia, 2018).

Bagi beberapa wanita, menggunakan lipstik bisa mendukung penampilan. Walaupun dari tahun ke tahun tren make up selalu berganti, tetapi masih banyak yang tetap menggunakan lipstik jenis matte karena beberapa alasan, antara lain memiliki pigmen warna yang kuat dibandingkan dengan jenis lipstik lain, sudah mengandung pelembap, ketika difoto tidak berkilau dan membuat penampilan tampak elegan serta dengan formula yang dibuat agar lebih tahan lama (Lie, 2016). 
Public Relations Manager Make Over, juga mengatakan kalau lipstik jenis matte menjadi favorit karena warnanya yang tahan lama, ringan dan tidak berminyak, warnanya lebih intens serta membuat bibir tidak kering karena mengandung mulai dari vitamin B kompleks hingga vitamin E (Alamanda, 2017). Wardah Exclusive Matte Lip Cream merupakan lushlip liquid dan colorbinding pigments dengan tesktur velvet creamy sekali oles, ringan, intens dan lembut, serta memberikan efek matte yang cepat kering dan tidak lengket (Wardah). Wardah juga menduduki peringkat teratas (TOP) untuk produk lipstik pada tahun 2017 sebesar 25,0\% (Top Brand Award, 2017).

Bauran promosi yang digunakan oleh Tokopedia adalah advertising, sales promotion, personal selling, direct marketing dan public relations sebagai cara untuk memperkenalkan Tokopedia (Nafisah \& Yusiana, 2017). Dalam penelitian ini hanya akan meneliti dua dari lima bauran promosi yang digunakan oleh Tokopedia. Kegiatan pemasaran langsung yang biasa dilakukan oleh Tokopedia yaitu dengan mengirimkan penawaran melalui e-mail, seperti informasi produk, cashback, diskon hingga tren terkini (Tokopedia, 2018). Sedangkan promosi penjualan yang telah dilakukan oleh Tokopedia yaitu dengan menggunakan voucher diskon dengan memasukkan kode tertentu dan hanya bisa menggunakan sekali dalam satu transaksi, hadiah, kontes hingga harga paket (Nafisah \& Yusiana, 2017).

Berdasarkan latar belakang yang sudah diuraikan, peneliti tertarik melakukan penelitian dengan judul Pengaruh Pemasaran Langsung dan Promosi Penjualan Terhadap Keputusan Pembelian Produk Wardah Exclusive Matte Lip Cream Di Tokopedia.

\section{Kajian Teoritis}

\section{Bauran Promosi}

Menurut Kotler dan Armstrong (2014, p.428-429) total promotion mix yang digunakan perusahaan, atau yang juga disebut dengan marketing communication mix, terdiri dari perpaduan yang spesifik dari advertising, public relations, personal selling, sales promotion, dan direct marketing yang digunakan perusahaan untuk mengkomunikasikan secara persuasif dan membangun hubungan dengan pelanggan. Kelima alat promosi tersebut didefinisikan sebagai berikut (Kotler \& Armstrong, 2014):

1. Advertising, adalah bentuk presentasi nonpersonal yang dibayar dan promosi dari ide, barang ataupun jasa oleh sponsor yang teridentifikasi.

2. Sales Promotion, adalah penawaran jangka pendek untuk mendorong pembelian maupun penjualan suatu produk atau jasa.

3. Personal Selling, adalah presentasi pribadi yang dilakukan oleh tenaga penjualan perusahaan untuk tujuan menghasilkan penjualan dan membangun hubungan dengan pelanggan.

4. Public Relations (PR), adalah untuk membangun hubungan baik berbagai perusahaan dengan mendapatkan publisitas yang menguntungkan, 
membentuk citra perusahaan yang baik, dan menangani atau mengemukakan rumor, cerita dan acara.

5. Direct Marketing, adalah hubungan langsung yang ditargetkan kepada individual konsumen untuk memperoleh respon secara cepat dan membangun hubungan pelanggan secara berkelanjutan.

Kaitannya dengan penelitian ini adalah karena variabel dalam penelitian ini adalah pemasaran langsung (direct marketing) dan promosi penjualan (sales promotion) yang merupakan bagian dari bauran promosi.

\section{Pemasaran Langsung}

Kotler dan Armstrong mengatakan bahwa pemasaran langsung adalah hubungan langsung yang ditargetkan kepada individual konsumen untuk memperoleh respon secara cepat dan membangun hubungan pelanggan secara berkelanjutan (2014, p.516). Sedangkan menurut Belch dan Belch (2012, p.470), pemasaran langsung adalah sistem pemasaran dimana suatu organisasi berkomunikasi secara langsung dengan target kostumer untuk menghasilkan respon ataupun transaksi. Berdasarkan uraian definisi yang telah dikemukakan, dapat dijelaskan bahwa pemasaran langsung adalah salah satu alat pemasaran yang digunakan perusahaan untuk mengkomunikasikan secara langsung dengan pelanggan secara individual untuk mendapat respon.

Program direct marketing dapat dirancang untuk mencapai beberapa alternatif tujuan berikut (Tjiptono \& Chandra, 2012):

1. Mendorong Leads atau Pencobaan Produk (product trial), direct marketing dapat dimanfaatkan untuk memperluas lingkup pelanggan perusahaan dengan cara menarik para non-pemakai ke pemakai produk tertentu.

2. Meningkatkan Kualitas Relasi dengan Pelanggan, melalui pengembangan database pelanggan yang memuat sejarah pembeliannya, perusahaan bisa melakukan seleksi segmen pasar dengan lebih akurat, menstimulasi pembelian ulang, dan mendapatkan gambaran lebih jelas mengenai level dan jenis bisnis tambahan yang bisa dikembangkan dari masing-masing individual.

3. Mempertahankan Pelanggan, dengan cara membuat berbagai program yang dirancang untuk mempertahankan pelanggan, misalnya seperti menawarkan kupon atau insentif.

4. Mengaktifkan Kembali Mantan Pelanggan, membuat program untuk merebut kembali pelanggan yang hilang karena tidak adanya variasi produk yang diinginkannya atau karena pengalaman buruk yang didapat saat pembelian sebelumnya.

Menurut Kotler \& Armstrong (2014) walaupun terdapat banyak bentuk pemasaran langsung, seperti direct mail dan katalog, online marketing, telephone marketing, dan lainnya, mereka terbagi menjadi 4 karakteristik khusus, yaitu:

1. Direct marketing is less public 
Secara umum, pesan ditujukan secara langsung kepada orang tertentu.

2. Direct marketing is immediate

Pesan dapat dipersiapkan dengan sangat cepat.

3. Direct marketing is customized

Pesan dapat disesuaikan untuk menarik konsumen tertentu.

4. Direct marketing is interactive

Ini memungkinkan terjadinya komunikasi antara marketer dengan konsumen, dan pesan dapat diubah tergantung respon yang diterima dari konsumen.

Kotler dan Armstrong (2014, p.521-524) menyebutkan bahwa bentuk utama dari pemasaran langsung antara lain face-to-face atau personal selling, direct-mail marketing, catalog marketing, telemarketing, direct-response-television (DRTV) marketing, kiosk marketing, dan online marketing.

a. Personal Selling: Presentasi pribadi yang dilakukan oleh tenaga penjualan perusahaan untuk tujuan menghasilkan penjualan dan membangun hubungan dengan pelanggan.

b. Direct-Mail Marketing: Pemasaran dengan mengirimkan penawaran, pengumuman, pengingat atau lainnya secara langsung kepada seseorang di alamat tertentu.

c. Catalog Marketing: Pemasaran langsung melalui video, katalog cetak maupun digital yang dikirimkan kepada pelanggan, tersedia di toko-toko atau diberikan secara online.

d. Telemarketing: Pemasaran langsung yang menggunakan telepon untuk menjual secara langsung ke pelanggan.

e. Direct-Response Television (DRTV) Marketing: Pemasaran langsung melalui televisi, termasuk respon langsung dari iklan televisi dan iklan interaktif di televisi.

f. Kiosk Marketing: Metode ini mirp dengan vending machines, pemasaran kios menawarkan pelanggan kesempatan untuk membeli dari fasilitas yang berada di area retail atau publik.

g. Online Marketing: Usaha memasarkan produk dan jasa serta membangun hubungan dengan pelanggan melalui internet.

\section{Promosi Penjualan}

Menurut Kotler dan Keller (2012, p.478), promosi penjualan merupakan berbagai insentif jangka pendek untuk mendorong pembelian suatu produk ataupun jasa, termasuk promosi konsumen (seperti sampel, kupon dan premi), promosi perdagangan (seperti iklan dan tunjangan tampilan), serta bisnis dan tenaga penjualan promosi (seperti kontes).

Menurut Tjiptono (2015, p.393), promosi penjualan cenderung efektif untuk: (1) Menciptakan respon pembeli yang kuat dan segera, (2) 
Mendramatisasi penawaran produk, dan (3) Mendongkrak penjualan dalam jangka pendek.

Promosi penjualan menawarkan 3 manfaat tersendiri (Kotler \& Keller, 2012, p.491) yaitu:

1. Ability to be attention-getting

Promosi penjualan dapat menarik perhatian dan mengarahkan konsumen ke produk tertentu.

2. Incentive

Promosi penjualan menggabungkan beberapa hak yang didapat, ajakan, atau kontribusi yang memberi nilai lebih pada konsumen.

3. Invitation

Promosi penjualan merupakan undangan untuk melibatkan konsumen untuk langsung melakukan transaksi saat itu juga.

Banyak alat yang bisa digunakan untuk mencapai tujuan promosi penjualan (Kotler \& Armstrong, 2014, p. 503-505).

1. Consumer Promotions

Sales promotion yang digunakan untuk meningkatkan pembelian dan keterlibatan konsumen dalam jangka pendek atau meningkatkan hubungan dengan konsumen dalam jangka panjang, mulai dari sampel, kupon, pengembalian uang, premi dan display pembelian untuk kontes, undian maupun sponsor acara.

2. Trade Promotions

Sales promotion yang digunakan untuk meyakinkan reseller untuk membawa sebuah merek, memberikan ruang pada rak jual, mempromosikan dalam iklan, dan mendorong agar konsumen mau membelinya. Produsen biasanya menawarkan barang gratis, diskon langsung dan juga menawarkan uang saku sebagai pengganti pengecer.

3. Business Promotions

Sales promotion digunakan untuk menghasilkan bisnis yang unggul, mendorong pembelian, memberikan penghargaan kepada pelanggan, dan memotivasi tenaga penjualan. Alat yang digunakan dalam business promotions hampir sama dengan customer atau trade promotions, hanya saja dalam bisnis fokus pada konvensi dan pameran dagang serta kontes penjualan.

\section{Keputusan Pembelian}

Kotler dan Armstrong (dalam Somad \& Priansa, 2014, p.100), mengatakan bahwa bagi pelanggan sebenarnya pembelian bukanlah hanya merupakan satu tindakan saja, melainkan terdiri dari beberapa tindakan yang saling berkaitan satu dengan lainnya. Menurut Peter dan Olson (dalam 
Sangadji \& Sopiah, 2013, p.332), pengambilan keputusan konsumen adalah proses pemecahan masalah yang diarahkan pada sasaran. Berdasarkan uraian definisi yang telah dikemukakan, dapat dijelaskan bahwa keputusan pembelian adalah proses untuk menentukan suatu tindakan melalui beberapa tahapan yang saling berkaitan.

Menurut Kotler, Keller, Ang, Leong, dan Tan (2009 p.180-186), 5 tahap proses keputusan pembelian terdiri dari:

Gambar 1. 5 Tahap Proses Keputusan Pembelian Konsumen

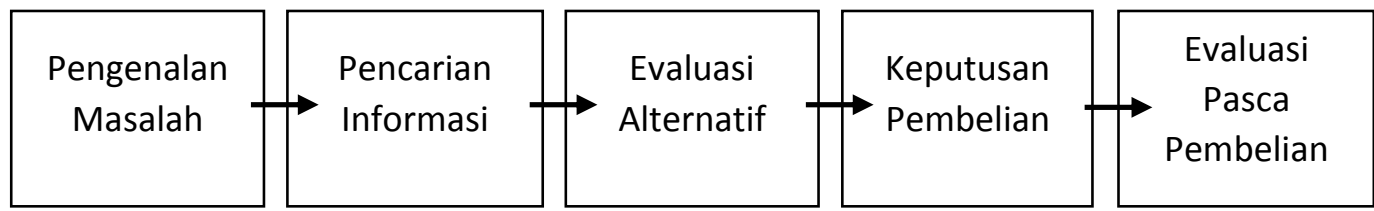

(Sumber: Kotler, Keller, Ang, Leong \& Tan, 2009, p.180)

1. Pengenalan Masalah

Pada tahap pertama diawali dengan adanya kebutuhan serta keinginan dari pelanggan, dimana para pelanggan menyadari bahwa adanya perbedaan antara keadaan sebenarnya dengan keadaan yang diinginkannya. Kebutuhan tersebut bisa mendapat rangsangan dari dalam diri maupun dari luar diri dari pelanggan.

2. Pencarian Informasi

Tahap kedua adalah pencarian informasi. Setelah pelanggan mengetahui apa yang dibutuhkan terhadap suatu produk tertentu, maka selanjutnya pelanggan akan mencari informasi mengenai produk yang dibutuhkannya tersebut, baik yang berasal dari pengetahuannya ataupun dari hasil pencariannya. Menurut Kotler, Keller, Ang, Leong dan Tan (2009, p.181), sumber informasi digolongkan menjadi 4 kelompok: (1) Sumber Pribadi, (2) Sumber Komersial, (3) Sumber Publik, dan (4) Sumber Pengalaman.

3. Evaluasi Alternatif

Setelah pelanggan telah mendapatkan informasi yang cukup mengenai produk yang dibutuhkannya, di tahap ini pelanggan mengevaluasi informasi-informasi tersebut untuk dijadikan pilihan dalam menentukan produk yang sesuai dengan kebutuhan.

4. Keputusan Pembelian

Jika pelanggan sudah menentukan pilihan produk yang sesuai dengan kebutuhannya, maka hasil akhir dari pencarian dan evaluasi yang telah dilakukan adalah memutuskan untuk membeli produk tersebut.

5. Evaluasi Pasca Pembelian 
Pada tahap terakhir ini, setelah pelanggan memutuskan untuk membeli dan sudah memakai produk tersebut, pelanggan akan memberikan penilaian. Jika produk itu tidak sesuai dengan apa yang dijanjikan dan pelanggan tidak merasa puas, maka pelanggan akan memberikan penilaian negatif atau bahkan tidak akan kembali membeli produk itu lagi. Tetapi sebaliknya, jika produk itu sesuai dan pelanggan merasa puas, maka keinginan untuk membeli lagi terhadap produk itu cenderung lebih besar.

Dimensi keputusan pembelian menurut Kotler dan Armstrong (dalam Somad \& Priansa, 2014, p.100) terdiri dari:

1. Pilihan Produk

Seorang pelanggan dapat mengambil keputusan untuk membeli sebuah produk yang sudah dipertimbangkan sebelumnya.

a. Keunggulan Produk: Tingkat kualitas yang diharapkan oleh pelanggan untuk produk pilihannya.

b. Manfaat Produk: Tingkat kegunaan yang dapat dirasakan oleh pelanggan dalam memenuhi kebutuhannya pada setiap produk pilihannya.

c. Pemilihan Produk: Pilihan pelanggan pada produk yang sudah dibelinya, yang sesuai dengan kualitas dan manfaat yang akan diperoleh.

2. Pilihan Merek

Setiap pelanggan harus menentukan merek mana yang akan dibeli. Dalam hal ini, pelanggan memilih sebuah merek berdasarkan ketertarikan, kebiasaan, atau kesesuaian.

a. Ketertarikan pada Merek: Ketertarikan pada citra merek yang sudah melekat pada produk.

b. Kebiasaan pada Merek: Pelanggan akan memilih dan membeli produk yang telah biasa digunakan olehnya.

c. Kesesuaian Harga: Pelanggan pasti akan mempertimbangkan harga yang sesuai dengan manfaat dan kualitas produk.

3. Pilihan Saluran Pembelian

Setiap pelanggan berbeda-beda dalam memutuskan manakah penyalur yang akan dikunjungi, tergantung dari faktor-faktor yang mempengaruhinya.

a. Pelayanan yang Diberikan: Pelanggan akan balik lagi ke toko atau distributor yang memberikan pelayanan yang baik serta kenyamanan berbelanja.

b. Kemudahan untuk Mendapatkan: Selain pelayanan yang baik, pelanggan juga akan merasa lebih nyaman jika lokasi mudah untuk dijangkau dan juga menyediakan barang-barang yang dibutuhkan. 
c. Persediaan Barang: Persediaan barang yang memadai pada suatu toko atau penyalur, akan membuat pelanggan memilih tempat tersebut untuk melakukan pembelian.

4. Waktu Pembelian

Pemilihan waktu pembelian setiap pelanggan berbeda-beda sesuai dengan kebutuhannya masing-masing.

a. Kesesuaian dengan Kebutuhan: Seseorang akan memutuskan untuk membeli ketika merasa perlu dan benar-benar membutuhkan produk tersebut.

b. Keuntungan yang Dirasakan: Pelanggan akan merasakan keuntungan sesuai dengan kebutuhannya melalui produk yang telah dibeli.

c. Alasan Pembelian: Setiap produk memiliki alasan untuk memenuhi kebutuhan pelanggan pada saat dibutuhkan.

5. Jumlah Pembelian

Seberapa banyak produk yang akan dibeli ditentukan sendiri oleh pelanggan pada saat membutuhkan produk tersebut.

a. Keputusan Jumlah Pembelian: Selain memilih merek yang sesuai, pelanggan juga menentukan jumlah produk yang akan dibelinya sesuai dengan kebutuhan.

b. Keputusan Pembelian untuk Persediaan: Pelanggan tidak hanya membeli untuk memenuhi kebutuhannya saat itu saja, tetapi juga membeli dengan tujuan untuk persediaan yang mungkin dibutuhkan pada saat mendatang.

\section{Metodologi}

Metodologi yang digunakan dalam penelitian ini adalah kuantitatif. Metode penelitian yang digunakan adalah survei dengan jenis penelitian eksplanatif kausalitas karena menjelaskan pengaruh pemasaran langsung (X1) dan promosi penjualan (X2) terhadap keputusan pembelian (Y). Populasi dalam penelitian ini adalah orang-orang yang memutuskan untuk membeli produk Wardah Exclusive Matte Lip Cream di Tokopedia. Namun banyaknya orang yang membeli Wardah Exclusive Matte Lip Cream di Tokopedia tidak diketahui secara pasti jumlahnya. Dikarenakan jumlah populasi dalam penelitian ini tidak diketahui secara pasti jumlahnya, maka menurut Hair, Black, Babin \& Anderson (2009) dalam penelitian regresi berganda membutuhkan sampel dengan jumlah minimal 50 dan sebaiknya 100 untuk melihat sebagian besar situasi penelitian. Maka sampel yang digunakan dalam penelitian ini berjumlah 107 responden dengan menggunakan teknik sampel simple random sampling. Data yang diperoleh dan dikumpulkan melalui penyebaran kuesioner yang dibagikan secara online kepada orang-orang yang memutuskan untuk membeli produk Wardah Exclusive Matte Lip Cream di Tokopedia. 


\section{Diskusi}

\section{Uji Validitas}

\section{Uji Validitas Variabel X1, X2 dan $Y$}

Pengujian validitas dalam penelitian ini dilakukan dengan menggunakan software SPSS versi 23 . Nilai $r_{\text {tabel }}$ yang digunakan sebagai dasar pembanding adalah 0,1900. Suatu pernyataan dikatakan valid apabila nilai rhitung $>r_{\text {tabel. }}$

Tabel 1. Hasil Uji Validitas Pemasaran Langsung (X1)

\begin{tabular}{llll}
\hline Pernyataan & $\begin{array}{l}\text { Corrected } \\
\text { Item-Total } \\
\text { Correlation } \\
\text { (rhitung) }\end{array}$ & r tabel & Keterangan \\
\hline X1.1 & 0,465 & 0,1900 & Valid \\
\hline X1.2 & 0,384 & 0,1900 & Valid \\
\hline X1.3 & 0,409 & 0,1900 & Valid \\
\hline X1.4 & 0,545 & 0,1900 & Valid \\
\hline X1.5 & 0,545 & 0,1900 & Valid \\
\hline X1.6 & 0,532 & 0,1900 & Valid \\
\hline X1.7 & 0,591 & 0,1900 & Valid \\
\hline X1.8 & 0,557 & 0,1900 & Valid \\
\hline X1.9 & 0,396 & 0,1900 & Valid \\
\hline X1.10 & 0,438 & 0,1900 & Valid \\
\hline X1.11 & 0,603 & 0,1900 & Valid \\
\hline X1.12 & 0,529 & 0,1900 & Valid \\
\hline X1.13 & 0,556 & 0,1900 & Valid \\
\hline X1.14 & 0,590 & 0,1900 & Valid \\
\hline X1.15 & 0,522 & 0,1900 & Valid \\
\hline X1.16 & 0,257 & 0,1900 & Valid \\
\hline
\end{tabular}

(Sumber: Data Olahan Peneliti, 2018)

Berdasarkan tabel 1 di atas, menunjukkan bahwa semua pernyataan variabel pemasaran langsung (X1) dinyatakan sebagai item yang valid. Hal ini dapat dilihat dari nilai $\mathrm{r}_{\text {hitung }}>$ nilai $\mathrm{r}_{\text {tabel, }}$ yaitu 0,1900. 
Tabel 2. Hasil Uji Validitas Promosi Penjualan (X2)

\begin{tabular}{llll}
\hline Pernyataan & $\begin{array}{l}\text { Corrected } \\
\text { Item-Total } \\
\text { Correlation } \\
\text { (ritung) }\end{array}$ & $\mathrm{r}_{\text {tabel }}$ & Keterangan \\
\hline X2.1 & 0,563 & 0,1900 & Valid \\
\hline X2.2 & 0,719 & 0,1900 & Valid \\
\hline X2.3 & 0,512 & 0,1900 & Valid \\
\hline X2.4 & 0,435 & 0,1900 & Valid \\
\hline X2.5 & 0,441 & 0,1900 & Valid \\
\hline X2.6 & 0,482 & 0,1900 & Valid \\
\hline X2.7 & 0,466 & 0,1900 & Valid \\
\hline X2.8 & 0,230 & 0,1900 & Valid \\
\hline X2.9 & 0,559 & 0,1900 & Valid \\
\hline X2.10 & 0,577 & 0,1900 & Valid \\
\hline X2.11 & 0,575 & 0,1900 & Valid \\
\hline X2.12 & 0,588 & 0,1900 & Valid \\
\hline
\end{tabular}

(Sumber: Data Olahan Peneliti, 2018)

Berdasarkan tabel 2, menunjukkan bahwa semua pernyataan variabel promosi penjualan (X2) dinyatakan sebagai item yang valid. Hal ini dapat dilihat dari nilai $r_{\text {hitung }}>$ nilai $r_{\text {tabel, }}$ yaitu 0,1900.

Tabel 3. Hasil Uji Validitas Keputusan Pembelian (Y)

\begin{tabular}{llll}
\hline Pernyataan & $\begin{array}{l}\text { Corrected } \\
\text { Item-Total } \\
\text { Correlation } \\
\text { (ritung) }\end{array}$ & $\mathrm{r}_{\text {tabel }}$ & Keterangan \\
\hline Y1 & 0,654 & 0,1900 & Valid \\
\hline Y2 & 0,667 & 0,1900 & Valid \\
\hline Y3 & 0,766 & 0,1900 & Valid \\
\hline Y4 & 0,691 & 0,1900 & Valid \\
\hline Y5 & 0,657 & 0,1900 & Valid \\
\hline Y6 & 0,690 & 0,1900 & Valid \\
\hline
\end{tabular}




\begin{tabular}{llll}
\hline Y7 & 0,483 & 0,1900 & Valid \\
\hline Y8 & 0,565 & 0,1900 & Valid \\
\hline Y9 & 0,680 & 0,1900 & Valid \\
\hline Y10 & 0,429 & 0,1900 & Valid \\
\hline Y11 & 0,621 & 0,1900 & Valid \\
\hline Y12 & 0,745 & 0,1900 & Valid \\
\hline Y13 & 0,742 & 0,1900 & Valid \\
\hline Y14 & 0,674 & 0,1900 & Valid \\
\hline Y15 & 0,634 & 0,1900 & Valid \\
\hline Y16 & 0,627 & 0,1900 & Valid \\
\hline Y17 & 0,707 & 0,1900 & Valid \\
\hline Y18 & 0,573 & 0,1900 & Valid \\
\hline Y19 & 0,686 & 0,1900 & Valid \\
\hline Y20 & 0,628 & 0,1900 & Valid \\
\hline Y21 & 0,690 & 0,1900 & Valid \\
\hline Y22 & 0,703 & 0,1900 & Valid \\
\hline Y23 & 0,664 & 0,1900 & Valid \\
\hline Y24 & 0,659 & 0,1900 & Valid \\
\hline Y25 & 0,524 & 0,1900 & Valid \\
\hline Y26 & 0,465 & 0,1900 & Valid \\
\hline Y27 & 0,373 & 0,1900 & Valid \\
\hline Y28 & 0,297 & 0,1900 & Valid \\
\hline
\end{tabular}

(Sumber: Data Olahan Peneliti, 2018)

Berdasarkan tabel di atas, menunjukkan bahwa semua pernyataan variabel keputusan pembelian $(\mathrm{Y})$ dinyatakan sebagai item yang valid. Hal ini dapat dilihat dari nilai $r_{\text {hitung }}>$ nilai $r_{\text {tabel, }}$ yaitu 0,1900.

\section{Uji Reliabilitas}

Uji Reliabilitas Variabel X1, X2 dan Y

Pengujian validitas dalam penelitian ini dilakukan dengan menggunakan software SPSS versi 23. Uji reliabilitas dalam penelitian ini menggunakan teknik Alpha Cronbach. Suatu instrumen penelitian dikatakan reliabel jika nilai Cronbach Alpha $>0,6$. 
Tabel 4. Hasil Uji Reliabilitas Pemasaran Langsung (X1)

\begin{tabular}{|c|c|c|}
\hline \multicolumn{3}{|c|}{ Reliability Statistics } \\
\hline & Cronbach's Alpha & \\
\hline $\begin{array}{l}\text { Cronbach's } \\
\text { Alpha }\end{array}$ & $\begin{array}{l}\text { Standardized } \\
\text { Items }\end{array}$ & $\begin{array}{l}\mathrm{N} \text { of } \\
\text { Items }\end{array}$ \\
\hline .863 & .864 & 16 \\
\hline
\end{tabular}

Berdasarkan tabel di atas, menunjukkan nilai Cronbach's Alpha sebesar 0,863 dengan jumlah item pertanyaan sebanyak 16 . Maka dapat disimpulkan bahwa pernyataan-pernyataan dalam variabel pemasaran langsung adalah reliabel karena 0,863>0,6.

Tabel 5. Hasil Uji Reliabilitas Promosi Penjualan (X2)

\begin{tabular}{ccc}
\hline \multicolumn{3}{c}{ Reliability Statistics } \\
Cronbach's Alpha \\
Based on \\
$\begin{array}{c}\text { Cronbach's } \\
\text { Alpha }\end{array}$ & $\begin{array}{c}\text { Standardized } \\
\text { Items }\end{array}$ & $\begin{array}{c}\mathrm{N} \text { of } \\
\text { Items }\end{array}$ \\
\hline .841 & .846 & 12 \\
\hline (Sumber: Data Olahan Peneliti, 2018)
\end{tabular}

Berdasarkan tabel 5 di atas, menunjukkan nilai Cronbach's Alpha sebesar 0,841 dengan jumlah item pertanyaan sebanyak 12. Maka dapat disimpulkan bahwa pernyataan-pernyataan dalam variabel promosi penjualan adalah reliabel karena 0,841 >0,6.

Tabel 6. Hasil Uji Reliabilitas Keputusan Pembelian (Y)

\begin{tabular}{ccc}
\hline \multicolumn{3}{c}{ Reliability Statistics } \\
Cronbach's Alpha \\
Based on \\
$\begin{array}{c}\text { Cronbach's } \\
\text { Alpha }\end{array}$ & $\begin{array}{c}\text { Items } \\
\text { Itemdized }\end{array}$ & $\begin{array}{c}\mathrm{N} \text { of } \\
\text { Items }\end{array}$ \\
\hline 945 & .950 & 28 \\
\hline (Sumber: Data Olahan Peneliti, 2018)
\end{tabular}

Berdasarkan tabel 6, menunjukkan nilai Cronbach's Alpha sebesar 0,945 dengan jumlah item pertanyaan sebanyak 28. Maka dapat disimpulkan bahwa 
pernyataan-pernyataan dalam variabel keputusan pembelian adalah reliabel karena $0,945>0,6$.

\section{Uji Normalitas}

Uji normalitas yang dilakukan pada penelitian ini menggunakan metode grafik P-Plot. Uji normalitas metode grafik P-Plot dideteksi dengan cara melihat penyebaran data sumber diagonal grafik Normal P-Plot of Regression Standardized Residual, jika menyebar sekitar garis dan mengikuti garis diagonal, maka residual pada model tersebut terdistribusi normal.

\section{Gambar 2. Hasil Uji Normal P-Plot}

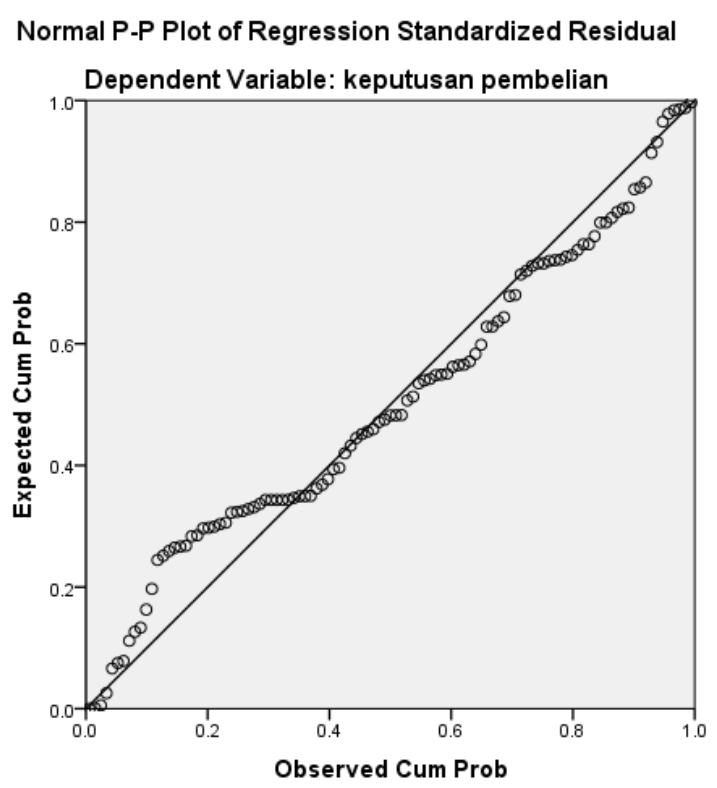

(Sumber: Data Olahan Peneliti, 2018)

Berdasarkan pada gambar di atas, dapat dilihat bahwa titik-titik menyebar disekitar garis dan arah penyebarannya mengikuti garis diagonal, maka hal ini menunjukkan bahwa data terdistribusi secara normal.

\section{Uji Linieritas}

Tabel 7. Hasil Uji Linieritas Pemasaran Langsung

ANOVA Table

\begin{tabular}{|c|c|c|c|c|c|c|}
\hline & & $\begin{array}{l}\text { Sum of } \\
\text { Squares }\end{array}$ & Df & $\begin{array}{l}\text { Mean } \\
\text { Square }\end{array}$ & $\mathrm{F}$ & Sig. \\
\hline \multirow{2}{*}{$\begin{array}{l}\text { Keputusan Betwee } \\
\text { Pembelian * } \mathrm{n}\end{array}$} & (Combined) & 5154.505 & 25 & 206.180 & 1.912 & .016 \\
\hline & Linearity & 3277.393 & 1 & 3277.393 & 30.397 & .000 \\
\hline
\end{tabular}




\begin{tabular}{llllllll}
\hline $\begin{array}{l}\text { Pemasaran } \\
\text { Langsung }\end{array}$ & Groups & $\begin{array}{c}\text { Deviation } \\
\text { from } \\
\text { Linearity }\end{array}$ & 1877.112 & 24 & 78.213 & .725 & .811 \\
& & & & & & \\
\cline { 2 - 7 } & Within & & 8733.383 & 81 & 107.820 & & \\
& Groups & & & & & \\
\cline { 2 - 7 } & Total & & 13887.888 & 106 & & \\
\hline
\end{tabular}

(Sumber: Data Olahan Peneliti, 2018)

Berdasarkan tabel di atas, diperoleh nilai signifikansi pada Linearity sebesar 0,000, yaitu kurang dari 0,05 dan juga hasil signifikansi pada Deviation from Linearity sebesar 0,811, yaitu lebih besar dari 0,05. Dengan begitu dapat disimpulkan bahwa antara variabel pemasaran langsung dengan keputusan pembelian terdapat hubungan yang linier, maka linieritas terpenuhi.

Tabel 8. Hasi Uji Linieritas Promosi Penjualan

\begin{tabular}{|c|c|c|c|c|c|c|c|}
\hline \multicolumn{8}{|c|}{ ANOVA Table } \\
\hline & & & $\begin{array}{l}\text { Sum of } \\
\text { Squares }\end{array}$ & $\mathrm{df}$ & $\begin{array}{l}\text { Mean } \\
\text { Square }\end{array}$ & F & Sig. \\
\hline \multirow{5}{*}{$\begin{array}{l}\text { Keputusan } \\
\text { Pembelian * } \\
\text { Promosi } \\
\text { Penjualan }\end{array}$} & \multirow{3}{*}{$\begin{array}{l}\text { Betwee } \\
n \\
\text { Groups }\end{array}$} & (Combined) & 8830.556 & 22 & 401.389 & 6.667 & .000 \\
\hline & & Linearity & 6940.323 & 1 & 6940.323 & 115.276 & .000 \\
\hline & & $\begin{array}{l}\text { Deviation } \\
\text { from } \\
\text { Linearity }\end{array}$ & 1890.233 & 21 & 90.011 & 1.495 & .101 \\
\hline & $\begin{array}{l}\text { Within } \\
\text { Groups }\end{array}$ & & 5057.332 & 84 & 60.206 & & \\
\hline & Total & & 13887.888 & 106 & & & \\
\hline
\end{tabular}

(Sumber: Data Olahan Peneliti, 2018)

Berdasarkan tabel di atas, diperoleh nilai signifikansi pada Linearity sebesar 0,000, yaitu kurang dari 0,05 dan juga hasil signifikansi pada Deviation from Linearity sebesar 0,101, yaitu lebih besar dari 0,05. Dengan begitu dapat disimpulkan bahwa antara variabel promosi penjualan dengan keputusan pembelian terdapat hubungan yang linier, maka linieritas terpenuhi.

\section{Uji Homogenitas}

Tabel 9. Hasil Uji Homogenitas Variabel X1

Test of Homogeneity of Variances

Keputusan Pembelian 


\begin{tabular}{cccc}
\hline $\begin{array}{l}\text { Levene } \\
\text { Statistic }\end{array}$ & df1 & df2 & Sig. \\
\hline 1.765 & 20 & 81 & .039 \\
\hline \multicolumn{4}{l}{ (Sumber: Data Olahan Peneliti, 2018$)$}
\end{tabular}

Berdasarkan tabel di atas, dapat dilihat bahwa nilai signifikansi sebesar 0,039, yaitu kurang dari 0,05. Maka dapat disimpulkan bahwa kelompok data dari pemasaran langsung mempunyai varian yang tidak sama.

Tabel 10. Hasil Uji Homogenitas Variabel X2

\begin{tabular}{llrl}
\hline \multicolumn{4}{l}{ Test of Homogeneity of Variances } \\
\hline \multicolumn{2}{l}{ Keputusan Pembelian } \\
$\begin{array}{l}\text { Levene } \\
\text { Statistic }\end{array}$ & df1 & df2 & Sig. \\
\hline 2.337 & 17 & 84 & .006 \\
\hline \multicolumn{4}{l}{ (Sumber: Data Olahan Peneliti, 2018) }
\end{tabular}

Berdasarkan tabel 10, dapat dilihat bahwa nilai signifikansi sebesar 0,006, yaitu kurang dari 0,05. Maka dapat disimpulkan bahwa kelompok data dari promosi penjualan mempunyai varian yang tidak sama.

\section{Uji Analisis Regresi Linier Berganda}

Analisis regresi linier berganda dilakukan untuk mengetahui apakah ada atau tidaknya pengaruh antara variabel bebas (independent), yaitu pemasaran langsung (X1), promosi penjualan (X2), terhadap variabel terikat (dependent), yaitu keputusan pembelian (Y).

Tabel 11. Hasil Uji Regresi Linier Berganda

\begin{tabular}{|c|c|c|c|c|c|c|}
\hline \multicolumn{7}{|c|}{ Coefficients $^{a}$} \\
\hline \multirow[b]{2}{*}{ Mode } & & \multicolumn{2}{|c|}{$\begin{array}{l}\text { Unstandardized } \\
\text { Coefficients }\end{array}$} & $\begin{array}{c}\text { Standardized } \\
\text { Coefficients }\end{array}$ & \multirow[b]{2}{*}{$\mathrm{T}$} & \multirow[b]{2}{*}{ Sig. } \\
\hline & & B & $\begin{array}{l}\text { Std. } \\
\text { Error }\end{array}$ & Beta & & \\
\hline \multirow[t]{3}{*}{1} & (Constant) & 28.581 & 9.290 & & 3.077 & .003 \\
\hline & $\begin{array}{l}\text { direct } \\
\text { marketing }\end{array}$ & .148 & 172 & .076 & .860 & .392 \\
\hline & $\begin{array}{l}\text { sales } \\
\text { promotion }\end{array}$ & 1.609 & .215 & .660 & 7.481 & .000 \\
\hline
\end{tabular}

(Sumber: Data Olahan Peneliti, 2018) 
Berdasarkan tabel 11, maka diperoleh persamaan model regresi sebagai

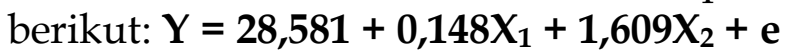

Persamaan linier tersebut dapat dijelaskan sebagai berikut:

1. Koefisien regresi variabel pemasaran langsung (X1), sebesar 0,148, artinya jika variabel independen lain nilainya tetap dan pemasaran langsung mengalami peningkatan sebesar 1, maka keputusan pembelian akan meningkat sebesar 0,148 kali atau dengan kata lain setiap peningkatan keputusan pembelian dibutuhkan variabel pemasaran langsung sebesar 0,148.

2. Koefisien regresi variabel promosi penjualan (X2), sebesar 1,609 , artinya jika variabel independen lain nilainya tetap dan promosi penjualan mengalami peningkatan sebesar 1, maka keputusan pembelian akan meningkat sebesar 1,609 kali atau dengan kata lain setiap peningkatan keputusan pembelian dibutuhkan variabel promosi penjualan sebesar 1,609 .

\section{Uji Analisis Korelasi Pearson}

Analisis korelasi pearson digunakan untuk mengetahui antara satu variabel dengan variabel lain secara linier (Priyatno, 2013).

Tabel 12. Hasil Analisis Korelasi Pearson

\begin{tabular}{|c|c|c|c|c|}
\hline \multicolumn{5}{|c|}{ Correlations } \\
\hline & & $\begin{array}{l}\text { Pemasaran } \\
\text { Langsung }\end{array}$ & $\begin{array}{l}\text { Promosi } \\
\text { Penjualan }\end{array}$ & $\begin{array}{l}\text { Keputusan } \\
\text { Pembelian }\end{array}$ \\
\hline \multirow{3}{*}{$\begin{array}{l}\text { Pemasaran } \\
\text { Langsung }\end{array}$} & Pearson Correlation & 1 & $.621^{* *}$ & $.486^{* *}$ \\
\hline & Sig. (2-tailed) & & .000 & .000 \\
\hline & $\mathrm{N}$ & 107 & 107 & 107 \\
\hline Promosi & Pearson Correlation & $.621^{* *}$ & 1 & $.707^{* \star}$ \\
\hline \multirow[t]{2}{*}{ Penjualan } & Sig. (2-tailed) & .000 & & .000 \\
\hline & $\mathrm{N}$ & 107 & 107 & 107 \\
\hline \multirow{3}{*}{$\begin{array}{l}\text { Keputusan } \\
\text { Pembelian }\end{array}$} & Pearson Correlation & $.486^{* *}$ & $.707^{* *}$ & 1 \\
\hline & Sig. (2-tailed) & .000 & .000 & \\
\hline & $\mathrm{N}$ & 107 & 107 & 107 \\
\hline
\end{tabular}

**. Correlation is significant at the 0.01 level (2-tailed).

(Sumber: Data Olahan Peneliti, 2018)

Dari tabel 12, dapat dilihat bahwa nilai korelasi antara variabel pemasaran langsung (X1) dengan keputusan pembelian (Y) adalah sebesar 0,486, yang berarti berada di range 0,40 - 0,599 maka dapat disimpulkan bahwa hubungan antara pemasaran langsung dengan keputusan pembelian adalah 
sedang. Nilai korelasi positif artinya terjadi hubungan yang positif, yaitu jika pemasaran langsung meningkat maka keputusan pembelian juga semakin tinggi. Selanjutnya, nilai korelasi antara variabel promosi penjualan (X2) dengan keputusan pembelian (Y) adalah sebesar 0,707, yang berarti berada di range 0,60 - 0,799 maka dapat disimpulkan bahwa hubungan antara promosi penjualan dengan keputusan pembelian adalah kuat. Nilai korelasi positif artinya terjadi hubungan yang positif, yaitu jika promosi penjualan meningkat maka keputusan pembelian juga semakin tinggi.

\section{Uji Koefisien Determinasi}

Koefisien determinasi adalah angka yang digunakan untuk mengetahui kontribusi atau sumbangan yang diberikan oleh sebuah variabel atau lebih $X$ (independen) terhadap Y (dependen) (Siregar, 2013).

Tabel 13. Hasil Koefisien Determinasi

\begin{tabular}{|c|c|c|c|c|}
\hline \multicolumn{5}{|c|}{ Model Summary } \\
\hline Model & $\mathrm{R}$ & R Square & $\begin{array}{c}\text { Adjusted R } \\
\text { Square }\end{array}$ & $\begin{array}{l}\text { Std. Error of } \\
\text { the Estimate }\end{array}$ \\
\hline 1 & $.709^{a}$ & .503 & .494 & 8.14445 \\
\hline
\end{tabular}

Berdasarkan tabel di atas, hasil uji koefisien determinasi diperoleh nilai $R$ square sebesar 0,503 (50,3\%). Hal ini menunjukkan bahwa persentase kontribusi variabel independen, yaitu pemasaran langsung dan promosi penjualan terhadap variabel dependen, yaitu keputusan pembelian sebesar $50,3 \%$. Sedangkan sisanya, sebesar 49,7\%, dipengaruhi oleh variabel lain yang tidak dijelaskan dalam penelitian ini.

\section{Uji Hipotesis}

\section{Uji t (Uji koefisien regresi secara parsial)}

Uji t digunakan untuk mengetahui apakah variabel independen secara parsial berpengaruh terhadap variabel dependen, dalam penelitian ini yaitu pemasaran langsung terhadap keputusan pembelian dan promosi penjualan terhadap keputusan pembelian. Angka $t_{\text {tabel }}$ dapat dilihat berdasarkan taraf signifikansi sebesar $5 \%$ dengan $(\mathrm{df})=\mathrm{n}-\mathrm{k}-1$, dimana $\mathrm{n}$ adalah jumlah sampel dan $\mathrm{k}$ adalah jumlah variabel independen, yaitu 107-2-1 = 104 (Priyatno, 2013). Maka angka $t_{\text {tabel }}$ yang didapat sebagai pembanding adalah 1,9830. 
Tabel 14. Hasil Uji t

\begin{tabular}{|c|c|c|c|c|c|c|}
\hline \multicolumn{7}{|c|}{ Coefficients $^{a}$} \\
\hline & & $\begin{array}{r}\text { Unstar } \\
\text { Coe }\end{array}$ & $\begin{array}{l}\text { lardized } \\
\text { icients }\end{array}$ & $\begin{array}{c}\text { Standardized } \\
\text { Coefficients }\end{array}$ & & \\
\hline \multicolumn{2}{|c|}{ Model } & B & Std. Error & Beta & $\mathrm{T}$ & Sig. \\
\hline \multirow[t]{3}{*}{1} & (Constant) & 28.581 & 9.290 & & 3.077 & .003 \\
\hline & $\begin{array}{l}\text { pemasaran } \\
\text { langsung }\end{array}$ & 148 & 172 & .076 & .860 & .392 \\
\hline & $\begin{array}{l}\text { promosi } \\
\text { penjualan }\end{array}$ & 1.609 & 215 & 660 & 7.481 & .000 \\
\hline
\end{tabular}

(Sumber: Data Olahan Peneliti, 2018)

Berdasarkan tabel 14, terlihat bahwa nilai variabel pemasaran langsung menghasilkan thitung $<t_{\text {tabel, }}$ yaitu $0,860<1,9830$ dan variabel promosi penjualan menghasilkan thitung $>t_{\text {tabel, }}$ yaitu $7,481>1,9830$. Hal ini menunjukkan bahwa keputusan yang diambil adalah menolak $\mathrm{H}_{\mathrm{a}} 1$ dan $\mathrm{H}_{0} 2$ serta menerima $\mathrm{H}_{0} 1$ dan $\mathrm{H}_{\mathrm{a}} 2$, maka dapat diartikan bahwa pemasaran langsung secara parsial tidak berpengaruh terhadap keputusan pembelian dan promosi penjualan secara parsial berpengaruh terhadap keputusan pembelian.

\section{Uji F (Uji koefisien regresi secara simultan)}

Uji F digunakan untuk menguji apakah variabel independen secara simultan berpengaruh terhadap variabel dependen, dalam penelitian ini yaitu pemasaran langsung dan promosi penjualan terhadap keputusan pembelian.

Tabel 15. Hasil Uji F

\begin{tabular}{llccccc}
\hline \multicolumn{7}{c}{ ANOVA $^{\mathbf{a}}$} \\
\multirow{2}{*}{ Model } & $\begin{array}{c}\text { Sum of } \\
\text { Squares }\end{array}$ & Df & Mean & & \\
\hline \multirow{2}{*}{1} & Square & F & Sig. \\
\cline { 2 - 7 } & Regression & 6989.354 & 2 & 3494.677 & 52.685 & $.000^{\mathrm{b}}$ \\
\cline { 2 - 7 } & Residual & 6898.534 & 104 & 66.332 & & \\
\cline { 2 - 7 } & Total & 13887.888 & 106 & & & \\
\hline
\end{tabular}

(Sumber: Data Olahan Peneliti, 2018) 
Berdasarkan tabel di atas, didapat nilai signifikansi sebesar 0,000 yang berarti $0,000<0,05$. Hal ini menunjukkan bahwa menolak $\mathrm{H}_{0} 3$ dan menerima $\mathrm{H}_{\mathrm{a}} 3$, maka dapat diartikan terdapat pengaruh pemasaran langsung dan promosi penjualan secara simultan terhadap keputusan pembelian produk Wardah Exlcusive Matte Lip Cream di Tokopedia.

\section{Kesimpulan}

Berdasarkan hasil analisis dan pembahasan penelitian, dapat disimpulkan bahwa:

1. Berdasarkan hasil uji $\mathrm{t}$ diperoleh nilai thitung pemasaran langsung sebesar 0,860 (0,860 kurang dari 1,9830), artinya pemasaran langsung secara parsial tidak berpengaruh terhadap keputusan pembelian produk Wardah Exlcusive Matte Lip Cream di Tokopedia. Hal ini dapat disebabkan karena mungkin Tokopedia mengirimkan penawaran-penawaran melalui e-mail tidak hanya untuk satu produk atau merek tertentu, misalnya Wardah, tetapi untuk semua produk yang dijualnya.

2. Berdasarkan hasil uji $t$ diperoleh nilai $t_{\text {hitung }}$ promosi penjualan sebesar 7,481 (7,481 lebih besar dari 1,9830), artinya promosi penjualan secara parsial berpengaruh terhadap keputusan pembelian produk Wardah Exlcusive Matte Lip Cream di Tokopedia.

3. Hasil Uji F diperoleh nilai sebesar 52,685 dan nilai Sig. 0,000 (0,000 kurang dari 0,05), yang berarti terdapat pengaruh pemasaran langsung dan promosi penjualan secara simultan terhadap keputusan pembelian produk Wardah Exlcusive Matte Lip Cream di Tokopedia.

4. Nilai korelasi antara variabel pemasaran langsung (X1) dengan keputusan pembelian (Y) adalah sebesar 0,486, maka dapat disimpulkan bahwa hubungan antara pemasaran langsung dengan keputusan pembelian adalah sedang dan positif.

5. Nilai korelasi antara variabel promosi penjualan (X2) dengan keputusan pembelian (Y) adalah sebesar 0,707, maka dapat disimpulkan bahwa hubungan antara promosi penjualan dengan keputusan pembelian adalah kuat dan positif.

6. Kontribusi variabel independen, yaitu pemasaran langsung dan promosi penjualan terhadap variabel dependen, yaitu keputusan pembelian sebesar 50,3\%. Sedangkan sisanya, sebesar 49,7\%, dipengaruhi oleh variabel lain yang tidak dijelaskan dalam penelitian ini.

7. Hasil uji regresi linier berganda menunjukkan persamaan model regresi $\mathrm{Y}=28,581+0,148 \mathrm{X}_{1}+1,609 \mathrm{X}_{2}$ yang artinya koefisien regresi variabel pemasaran langsung $(X 1)$, sebesar 0,148 , ini berarti setiap peningkatan keputusan pembelian dibutuhkan variabel pemasaran langsung sebesar 0,148. Koefisien regresi variabel promosi penjualan (X2), sebesar 1,609, yang artinya setiap peningkatan keputusan pembelian dibutuhkan variabel promosi penjualan sebesar 1,609. 


\section{Daftar Pustaka}

Abdurrahman, M. S. (2017, Mei 20). "Pertumbuhan e-Commerce Indonesia Tertinggi di Dunia." Diperoleh dari: http://tekno.liputan6.com/read/2957050/pertumbuhan-e-commerceindonesia-tertinggi-di-dunia

Alamanda. (2017, November 22). "4 Alasan Mengapa Lipstik Matte Makin Digemari." Diperoleh dari: https://www.gulalives.co/4-alasanmengapa-lipstik-matte-makin-digemari/

Belch, G. E. \& Belch, M. A. (2012). Advertising and Promotion, An Integrated Marketing Communications Perspective. Singapore: McGraw-Hill.

Hair, J. F., Black, W. C., Babin, B. J., \& Anderson, R. E. (2009). Multivariate Data Analysis 7th Edition.

Kotler, P., Keller, K. L., Ang, A. H., Leong, S. M., \& Tan, C. T. (2009). Marketing Management. Singapore: Pearson Education South Asia Pte Ltd.

Kotler, P., \& Keller, K. L. (2012). Marketing Management. New Jersey: Pearson Education, Inc.

Kotler, P., \& Armstrong, G. (2014). Principles Of Marketing. England: Pearson Education Limited.

Kusumaningrum, D. (2018, Januari 27). "Tokopedia Dinobatkan Sebagai Tempat Belanja Online Nomor 1 Indonesia." Diperoleh dari: https://www.wartaekonomi.co.id/read168795/tokopedia-dinobatkansebagai-tempat-belanja-online-nomor-1-indonesia.html

Lie, C. (2016, November 19). "5 Alasan Lipstik Matte Masih Digemari." Diperoleh dari: https://journal.sociolla.com/alasan-lipstik-matte-masihdigemari/

Maryanto, H. (2017, April 29). "E-Commerce dan E-Business." Diperoleh dari: http://scdc.binus.ac.id/himti/2017/04/29/e-commerce-dan-ebusiness /\#

Nafisah, A. \& Yusiana, R. (2017). E-Proceeding of Applied Science. Analisis Promotion Mix Pada Tokopedia tahun 2017, 3(3), 1129-1134. Diperoleh dari

http:/ / openlibrary.telkomuniversity.ac.id/pustaka/files/137107/jurnal eproc/analisis-promotion-mix-pada-tokopedia-tahun-2017.pdf

Noviandari, L. (2014, Oktober 24). "5 Hal Menarik Yang Perlu Anda Ketahui Tentang Tokopedia." Diperoleh dari: https://id.techinasia.com/daftarfakta-menarik-tentang-tokopedia-william-tanuwijaya

Priyatno, D. (2013). Mandiri Belajar Analisis Data dengan SPSS. Yogyakarta: Mediakom 
Rahman, A. F. (2017, September 5). "Masyarakat Indonesia Makin Doyan Belanja Online, Tapi..." Diperoleh dari: https:/ /inet.detik.com/cyberlife/d-3630020/masyarakat-indonesiamakin-doyan-belanja-online-tapi

Sangadji, E. M., \& Sopiah. (2013). Perilaku Konsumen. Yogyakarta: Andi.

Siregar, S. (2013). Metodologi Penelitian Kuantitatif. Jakarta: Kencana.

Somad, R., \& Priansa, D. J. (2014). Manajemen Komunikasi Mengembangkan Bisnis Berorientasi Pelanggan. Bandung: Alfabeta.

Tjiptono, F., \& Chandra, G. (2012). Pemasaran Strategik. Yogyakarta: Andi

Tjiptono, F. (2015). Strategi Pemasaran. Yogyakarta: Andi.

Tokopedia. (n.d.). "Tentang Kami." Diperoleh dari: https://www.tokopedia.com/about/

Top Brand Index 2017 Fase 1. (2017). "Top Brand Fase 1 2017." Diperoleh dari: http://www.topbrand-award.com/top-brand-survey/surveyresult/top_brand_index_2017_fase_1

Wardah. (n.d.). "Exclusive LipCream." Diperoleh dari: http://www.wardahbeauty.com/products/detail/exclusive-lipcream 